\title{
New robertinid foraminifers from the Early Jurassic of Adnet, Austria and their evolutionary importance
}

Sylvain Rigaud and Joachim Blau

Acta Palaeontologica Polonica 61 (4), 2016: 721-734 doi:http://dx.doi.org/10.4202/app.00250.2016

New benthic multichambered foraminifers have been discovered in the Hettangian-Sinemurian of the Northern Calcareous Alps (Adnet, Salzburg, Austria). Originally aragonitic, these forms are completely recrystallized but the early impregnation of their tests by Fe-Mn solutions has, to some extent, allowed an indirect preservation of their primary structure. The most remarkably preserved specimens are found in close vicinity to the marmorea crust, a heavily mineralized multiphased hardground. We describe two new genera, Velleditsiella gen. nov., a microgastropod look-alike foraminifer, which includes the species $V$. felicitaszae gen. et sp. nov. and V. spinaferra gen. et sp. nov., and Rossanella gen. nov., the first known representative of the superfamily Conorboidoidea, which includes the species $R$. martinii gen. et sp. nov. Considering their structural and morphological characteristics, Velleditsiella and Rossanella phylogenetically derive from two distinct Triassic lineages, respectively the families Trochosiphoniidae and Variostomatidae. The discovery of diverse aragonitic assemblages in earliest Jurassic strata dismisses the long believed hypothesis that all Jurassic aragonitic multichambered foraminifers originated from a single Oberhauserellidae ancestor. It also supports a lower impact of the Triassic/Jurassic biotic crisis on the evolution of aragonitic foraminifers. Hypotheses for the short term and long term evolution of aragonitic multichambered foraminifers are discussed and new phyletic trees are proposed.

Key words: Robertinida, Trochosiphoniidae, Conorboididae, inner-chamber structures, marmorea crust, Jurassic, Austria.

Sylvain Rigaud [SRigaud@ntu.edu.sg], Earth Observatory of Singapore, 50 Nanyang Avenue, 639798 Singapore, Singapore. Joachim Blau [Joachim.Blau@geolo.uni-giessen.de], Geozentrum, FE Geologie, Altenhöferallee 1, 60438 Frankfurt am Main, Germany. 
This is an open-access article distributed under the terms of the Creative Commons

Attribution License (for details please see creativecommons.org), which permits unrestricted use, distribution, and reproduction in any medium, provided the original author and source are credited.

FoF Full text $(1,113.2 \mathrm{kB})$ 